\title{
The Data Swamp: Trends from the Academic Business Library Directors' Year in Review Report 2017-2018
}

\author{
CHRISTINA SYLKA \\ University of British Columbia \\ christina.sylka@ubc.ca \\ ZAIDA DIAZ \\ University of Maryland \\ zdiaz@umd.edu \\ LEIGH PLUMMER \\ University of Maryland \\ leighplu@umd.edu
}

\begin{abstract}
A summary of academic business library trends from the Academic Business Library Directors (ABLD) Year in Review report 2017-2018. Areas covered include new and ongoing initiatives, organizational changes, physical space changes and collection and vendor issues related to ABLD member libraries. The paper also highlights major issues, organizational changes and new initiatives related to ABLD member business schools.
\end{abstract}

Keywords academic business libraries, library trends, organizational changes, new initiatives, business schools, Academic Business Library Directors (ABLD)

\section{Year in Review}

In preparation for the Academic Business Library Directors' (ABLD) annual spring meeting, individual ABLD members each submit an annual report that summarizes new and ongoing initiatives, organizational changes, physical space changes and collection and vendor issues related to their libraries. They also summarize issues, organizational changes and new initiatives related to their business schools. This year's annual meeting took place in Seattle at the University of Washington from May 8-11, 2018. The theme for the meeting was the Data Deluge. Each meeting includes a presentation summarizing major themes from the Year in Review. This presentation is framed by a unifying metaphor that complements the meeting theme. This year, that unifying metaphor was the Data Swamp.

Swamps have an unfair reputation in the popular imagination as waste land, toxic, dangerous and ready to be drained. However, "... despite its outward appearance, a healthy swamp is a rich, diverse, sometimes messy ecosystem. One in which a profusion of plants and animals thrive in happy symbiosis or grudging respect" with no expectation that everything needs to conform to a single pattern (Nevala, 2018). Academic business libraries share this capacity and flexibility in supporting the diverse and messy spectrum of academic life uniquely, using spaces, services and collections to accommodate the entry level needs of first year undergraduates, the advanced, interdisciplinary data needs of faculty and the various needs of entrepreneurship, innovation and emerging technologies. 
Ticker: The Academic Business Librarianship Review, 3:2 (2019)

http://dx.doi.org/10.3998/ticker.16481003.0003.202

(c) 2019 Christina Sylka, Zaida Diaz and Leigh Plummer

\section{Notable Trends Overall}

Swamps are incredibly productive: "wetlands are among the most productive ecosystems in the world, comparable to rain forests and coral reefs" (U.S. Environmental Protection Agency, 2016). Academic business library ecosystems are similarly prolific. Overall, the demand for instruction is increasing, the need for and access to online resources is proliferating, the demand for support for data acquisition, visualization and analytics is multiplying, entrepreneurship programs are expanding and spaces are both heavily used and being renovated. All of this activity is taking place within a shifting and dynamic organizational environment, with significant staff and librarian turnover and structural and organizational change occurring within both the larger library systems and the business schools.

\section{Data, Data, Data}

The Data Deluge was the theme for the 2017/18 ABLD Meeting. This past year, data has a significant driver of the external facing work of ABLD members' services, facilities and collection development roles. These include managing requests from and identifying resources for faculty and graduate students; acquiring, licensing, managing and trouble-shooting the data sets; and designing spaces and delivering learning opportunities in support of data visualization and analytics.

A substantial desire among graduate students and faculty for unique data sets was noted in the reports of the University of Maryland, Wake Forest, the University of British Columbia, New York University, Penn State, and Indiana University (ABLD, 2018, pp. 83, 28, 15, 31, 72 \& 51). Penn State also noted that these requests are coming from disciplines outside of business and economics (ABLD, 2018, p. 72). Dartmouth emphasized that its rising data demand included requests for geospatial and mapping data in subject domains such as energy (ABLD, 2018, p.75). Cornell highlighted how text mining and sentiment analysis continue to be of interest to faculty and $\mathrm{PhD}$ students but acknowledged that finding funding for and determining availability of these resources remain challenging ( $A B L D, \underline{2018}$, p. 16).

Data also infused internal activities, as libraries gather assessment- and use- data in support of more evidence-based decision making in business design, space and service allocation, and collection renewals. During 2017/18, four institutions embarked on or were planning space assessments. HEC Montréal's Library revised its entire business model in a year long process in order to focus on research data and knowledge management and employed "an optimisation approach process", analyzing circulation desk and user traffic data to advocate for extending the Library's opening hours (ABLD, 2018, p.79). Southern Methodist University gathered true assessment data of its Information Literacy Plan for undergraduates (ABLD, 2018, p. 39). Purdue just completed a year long review of the Parrish Library space to gather user feedback about the current use of the space and to suggest future changes. The University of Chicago conducted space assessment across the libraries. Duke University noted that metrics from database vendors can provide useful information during the renewal decision making process but that, "unfortunately, vendor metrics are often: inconsistent; unshared ... irrelevant (market value of content) and inappropriately applied (pricing based on institutional prestige, size of endowment)" (ABLD, 2018, $p$. 24). The University of Illinois would like ABLD to work with vendors to get better and more meaningful usage metrics (ABLD, 2018, p. 57). 
Ticker: The Academic Business Librarianship Review, 3:2 (2019)

http://dx.doi.org/10.3998/ticker.16481003.0003.202

(c) 2019 Christina Sylka, Zaida Diaz and Leigh Plummer

\section{Entrepreneurship and Innovation Programs are on the Rise}

Increased campus interest in entrepreneurship and innovation was realized in ABLD member libraries and business schools in a variety of ways. Purdue identified a growing demand for entrepreneurship collaborations; the University of Washington launched a new Masters of Science in Entrepreneurship; Penn State's business school introduced two new entrepreneurship programs and the library hired its first entrepreneurship librarian; the University of Pittsburgh's Chancellor identified innovation and entrepreneurship as priorities, and the library started an Entrepreneurship Research Interest Group (ABLD, 2018, pp. 9, 26, 71-72 \& 47). The University of California Berkeley identified an increase in shortterm, non-degree entrepreneurship programs in UC Berkeley schools and research centers (ABLD, 2018, p. 53). The University of Maryland Libraries partnered with campus stakeholders "to develop a "start-up hub" within the UM Libraries' Research Commons to bring a consultation team approach and programming on various aspects of support needed in areas of Business/Market Research/New Product Development; Grants; Data Analytics/Data Repositories; GIS Services; Patents/Trademarks/Copyright, etc." (ABLD, 2018, p. 83) Both HEC Montréal and New York University partnered with the University of Toronto's Rotman School of Management Creative Destruction Lab, a program designed to maximize value for science and technology start-ups (ABLD, 2018, pp. 80 \& 32). Boston University's library connected with the IDG Capital Student Innovation Center (BUild Lab) to communicate how library's resources and services can support new ventures (ABLD, 2018, p. 22).

\section{Raising the Profile of Diversity, Inclusivity, and Social Justice}

MIT's report highlighted the fact that campuses are committing to and raising the visibility of diversity, inclusivity and social justice issues (ABLD, 2018, p. 41). Vanderbilt University has hired a Vice Provost for Inclusive Excellence and the business school devoted significant time to inclusivity during orientations; Indiana University Libraries released its IU Libraries Diversity Strategic Plan (ABLD, 2018, pp. 46 \& 50). In April, 2018 the University of British Columbia (UBC) opened the Indian Residential School History and Dialogue Centre and issued a Statement of Apology for UBC's "involvement in the system that supported the operation of the Indian Residential Schools" (UBC, 2018).

\section{Increasing Demand for Teaching, Training, and Outreach}

In her presidential address at the Fall 1994 meeting of the Association for Public Policy Analysis and Management, Ellen Schall employed the metaphor of the swamp as a way to understand the important, complex, and messy problems, resistant to technical analysis, that are part of public service leadership. In order to be effective in public leadership, people need to lead and manage in the swamp, understanding the reality of their complex, messy world, and to be able "to reflect on and learn from your own and others' experience to make sense of things" (Schall, 1995, p. 203). Schall's metaphor is resonant for academic business librarians in leadership roles, and also for those who design, deliver, and advocate for instruction, reference and outreach in a constantly shifting environment. The metaphor of a complicated and convoluted landscape also reflects the experience of patrons trying to navigate the complex world of business research resources and data, which is way instruction and outreach remain such vital activities.

ABLD member reports identified growth in instructional load, demand for programs and demand for research support. Thirteen institutions identified an increasing number of requests for in-person and 
Ticker: The Academic Business Librarianship Review, 3:2 (2019)

http://dx.doi.org/10.3998/ticker.16481003.0003.202

(c) 2019 Christina Sylka, Zaida Diaz and Leigh Plummer

online instruction, and six identified newly initiated or continued programs, workshops or courses. Four libraries had new or re-designed online presences, and three identified increased research consultations and program attendance.

ABLD member libraries offer a broad spectrum of instruction, programming and outreach, ranging from workshops to in-class instruction to for-credit courses, to course integrated sessions, to online tutorials. Instruction activities manifest differently in different libraries, reflecting the institutional ecosystems in which those libraries operate. Penn State's instruction program continues to grow, with librarians conducting almost 245 instruction and outreach sessions (ABLD, 2018, p. 71). Michigan State University business librarians continued to be heavily involved with instruction, including teaching a 3credit business information literacy course (ABLD, 2018, p. 70). UBC's co-curricular programming in the forms of Writing Coaching, Peer Assisted Study Sessions, and Bloomberg and Capital IQ workshops were well-attended, with attendance at PASS sessions rising 43\% from the previous year (ABLD, 2018, p. 13). Wake Forest cited challenges in securing time for the library in undergraduate orientations; the University of Pennsylvania experienced its first year of Wharton 101, the new foundational class for Wharton undergraduates, and, as a way of finding a niche, the library experimented with creating a LibWizard tutorial focused on finding articles (ABLD, 2018, p. $18 \& 20$ ).

Experimenting with new techniques, exploring new technologies or platforms, assessing existing programs and reflecting on instructional practice offer avenues to enhance the impact of libraries' instructional roles. Yale's Reference Instruction and Outreach group worked with the Yale Center for Teaching and Learning to host a series of three workshops that offered librarians a forum to develop their skills and discuss emerging trends in instruction (ABLD, 2018, p. 36). Southern Methodist University completed its first year of the EMBA Library Research Program, building on four previous years of the Outreach to EMBA program (ABLD, 2018, p. 39). HEC Montréal discussed integrating library resources, and access to case studies and course material into ZoneCours 2.0, with dynamic electronic links to the library's e-resources (ABLD, 2018, p.80). The University of Michigan library launched its new website, explored using new platforms like Blue Jeans to instruct students, began library information sessions for alumni, integrated library instruction in new courses, and obtained a new reference desk and an improved service point for the exam review program (ABLD, 2018, pp. 60-62). Michigan State University provided increased support to students enrolled in online graduate degree programs, launched a chat service, and automated the process of linking their LibGuides in the course management system (ABLD, $\underline{2018}$, p.68)

\section{Organizational Changes and New Staff}

Swamps are transition areas-not quite water, not quite forest-and are often temporary homes for migrating birds (New Hampshire PBS, 2018). The most significant areas for transition and upheaval for ABLD member libraries were related to staff and librarian turnover and organizational change. Eighteen institutions hired or were in the process of hiring new librarians; seventeen positions were vacated, left open, or lost. Ten member libraries experienced reorganization within their departments. Nine institutions spoke to the slow search processes involved in hiring in an academic environment. The leaders of seven member institutions had title changes or increased responsibilities; six institutions hired new staff and six hired new administration. 
Ticker: The Academic Business Librarianship Review, 3:2 (2019)

http://dx.doi.org/10.3998/ticker.16481003.0003.202

(c) 2019 Christina Sylka, Zaida Diaz and Leigh Plummer

Brand new positions were approved at Harvard, Yale and the University of Pittsburgh (ABLD, 2018, pp. 33-35, 37 \& 48) Vacant positions, retirements or positions not approved or lost through restructuring included Cornell, Emory, Yale, Southern Methodist University and Vanderbilt (ABLD, 2018, pp. 16, 18-19, 37, 40 \& 45). MIT articulated the challenges of succession planning (ABLD, 2018, p. 41). Northwestern explained that turnover in key positions has led reorganizations in public services (ABLD, 2018, p.44). At Notre Dame the Collections Strategy and Subject Services Program was reorganized again (ABLD, 2018, p. 5). At the University of Alabama both the business branch head and the business collections manager had significant increases in responsibility across multiple branches (ABLD, 2018, p. 6). UCLA experienced change at the top administrative level, with the Deputy University Librarian became University Librarian at UBC, as well as across the libraries, due to the User Engagement reorganization in July 2017 which resulted in the formation of five functional teams (FT) -- Collections, Outreach, Research Assistance, Research Partnerships, and Teaching and Learning (ABLD, 2018, p. 10). The University of Washington's Libraries introduced a new reporting structure in the branch libraries, "where classified staff report to a central operations manager and subject librarians report to a research services director" (ABLD, 2018, p.26). At Western University, the libraries also underwent an organizational renewal that raised concerns in the business library that the level of support traditionally provided will decrease due to the staffing changes that are being implemented (ABLD, 2018, p.42).

The University of Toronto's administrative relationship changed from reporting to the business school to reporting to the library, and this change has resulted in collection issues becoming more straightforward, more databases being acquired this year then ever before, and evidence of continued relationship building with the central library being a boon to the business library and the business school (ABLD, 2018, p. 58).

Emory and Harvard reflected on the challenge of finding experienced talent in the workforce (ABLD, $\underline{2018}$, pp. 18 \& 35). Harvard's Baker Library acknowledged that, as their products and services become more diverse and technology driven, there has an impact on the traditional make-up of staff and librarians: "attracting specialized skill sets to what seems a very "academic" setting plus onboarding and growing ... capabilities is extremely difficult. Our searches for these non-traditional library skill sets are increasing in length... [as we work to] articulate what we need and build a quality candidate pool." (ABLD, 2018, p. 35)

\section{Facilities}

Filip Tkaczyk writes that "the fluctuating levels of water in a swampland can itself be both a blessing and a challenge, and permanent structures in such landscapes must be able to adapt to such changes." (Tkaczyk, $\underline{\text { n.d. }}$ ). In this aspect, the swamp metaphor is resonant for academic business libraries, as well. They operate in shifting environments, changing their physical facilities to meet patron needs and demands more fully, working within existing constraints, and working within larger campus ecosystems in which other partners may compete for their space or other factors lead to the erosion of the physical facilities.

During 2017/18, eighteen institutions either had completed, were in the midst of embarking on, or were planning to embark on renovations to their spaces. Four institutions either lost or re-allocated their collections' spaces to study or office space. Three institutions had offices or spaces that were either 
Ticker: The Academic Business Librarianship Review, 3:2 (2019)

http://dx.doi.org/10.3998/ticker.16481003.0003.202

(c) 2019 Christina Sylka, Zaida Diaz and Leigh Plummer

moved or moving; three institutions received new furniture; physical collections of two institutions were being or about to be moved, and two libraries were renamed.

From August 2017 until May 2018 the University of Wisconsin - Madison's Business Library was closed, renovated and combined with other spaces to form a Business Learning Commons, resulting in a 10,000 square foot increase and an additional 200 seats (ABLD, 2018, p.1). Vanderbilt's total renovation of its business library was completed in August 2017 (ABLD, 2018, pp. 45-46). The University of Pittsburgh, Indiana University and the University of Southern California all had had library spaces that were recently or are currently being renovated (ABLD, 2018, pp. 58, $51 \& 2$ ). The University of Maryland renovated its Research Commons (ABLD, 2018, p. 83). Georgetown received new carpet, new cubicles and less workspace. As a response to growing enrollment at Yale College and the opening of two new residential colleges near the library, Yale completed a renovation that resulted in a new seminar room, map room with consultation space, AV studio for producing videos and web tutorials, and a variety of new study spaces for students with 65 additional seats (ABLD, 2018, p. 37).

UC Berkeley has been approached by its business school to discuss giving up the lower level in exchange for a complete renovation of the upper level (ABLD, 2018, p. 52). The University of Illinois' Business Information Services was moved out of the business school during a renovation and doesn't expect to return even after they have finished (ABLD, 2018, p. 56). Michigan State University libraries launched a new Digital Scholarship Lab and, in response to demands for more collaborative space, created four group rooms, each containing a large screen TV and AirMedia technology that enable patrons to project wirelessly from their device/computer to the screen (ABLD, 2018, pp. 68-69).

Emory's library will be acquiring all new furniture for its offices over the summer, and the design will accommodate and align with use patterns, including regular team consultations (ABLD, 2018, p. 18). Duke is working on a new plan to reconfigure its reading room, replacing some book stacks with new study tables to add an additional forty seats; Babson has an upcoming renovation, and Dartmouth's Feldberg Library building is scheduled for a renovation in 2019 (ABLD, 2018, pp. 24, 77 \& 75).

The University of Southern California's Crocker Business Library was renamed the Gaughan \& Tiberti Library, and the University of Toronto's Business Information Centre was renamed the Milt Harris Library (ABLD, 2018, pp. 2 \& 58).

\section{Collections and Vendor Issues}

A swamp is "defined as a wetland dominated by trees or dense shrub thickets..." (Shaw, 2018), and a library is often defined by its collections, at least to people outside the library. Collections remain a source of significant activity for ABLD member libraries. One hundred and seven new databases/datasets/modules acquired or added during 2017/2018, while sixty-five subscriptions were either cancelled or reduced. Eleven institutions identified an increased focus on assessing online resources, while ten institutions commented on the increased number of online resources. Ten institutions spoke to vendor relationships, particularly challenges in communicating and negotiating licenses with and obtaining useful metrics from vendors. Four institutions discussed the impact of flat or reduced budgets, as well as cuts resulting from consortia agreements. Two libraries (Babson and the University of Washington) highlighted deselection and weeding activities (ABLD, 2018, pp. 26). 
The University of Toronto acknowledged that greater nimbleness is needed when considering either the acquisition or cancellation of resources (ABLD, 2018, p. 58). Flat or decreased collections budgets were specifically noted by Cornell and the University of Washington (ABLD, 2018, pp. 16 \& 26). Impacts of consortia cost changes were noted by UCLA and Cornell; the University of Chicago is in the beginning stages of joining the Big Ten Academic Alliance shared print repository (ABLD, 2018, pp. 10, 16 \& 54). The University of Pennsylvania loaded about 2,200 papers from Wharton faculty into Scholarly Commons, their institutional repository, after many years of outreach and relationship building (ABLD, 2018, p. 20).

The University of Pennsylvania highlighted challenges in negotiating with new vendors, which leads to long delays in getting access to new resources, or long delays in NOT getting access to new resources. We are also experiencing more difficulty than seems reasonable in working out contract language with existing vendors ..." (ABLD, 2018, p. 21). Carnegie Mellon and MIT both acknowledged frustration with downloading restrictions from certain business resources, which make it hard to create data sets for faculty and PhD research (ABLD, 2018, p. 29 \& 41).

The University of Toronto, Western and HEC Montréal all mentioned the Canadian dollar as an issue that affected collections, but HEC Montréal confirmed that good vendor relationships and vendor understanding of the impact of the exchange rate meant that the library was able to retain its current subscriptions (ABLD, 2018, pp. 58, $42 \& 79$ ).

\section{Business School Issues and New Initiatives}

One of the vital functions that wetlands perform is that they "will slow down the progress of a storm surge" (Masters, $\underline{\text { n.d. }}$ ). Academic business libraries are deeply connected with the business schools that they support, and changes or storms in those environments affect and have impact on these libraries.

During 2017/2018, the business schools supported by ABLD members experienced tremendous change. Seventeen business schools were either establishing new or expanding existing programs, certificates, institutes or centers. Ten institutions had either hired or were in the process of searching for a new dean. Program directors or top administrators from nine business schools had either left are were in the process of leaving their positions. Seven business schools were looking to cost share or expand programs with other schools or programs. Other trends identified by at least two institutions were increased focus on faculty research support, new faculty hires and increased support of students and families. Two business schools were working through reorganizations, two received major grants, two were focusing more on specific industries and two were splitting or reconfiguring their focuses.

Administrative changes or reorganizations within business schools often surface vulnerabilities in funding structures. If a new Dean decides to make strategic investments in non-library areas, such as faculty development, student scholarships, or new programs, the library may face competition for funding. Expanding or establishing programs, certificates, and institutes, as well as fostering formal cross-campus relationships also has an impact on libraries' service models, particularly if the libraries are asked to provide increased support, without additional funding. 
Ticker: The Academic Business Librarianship Review, 3:2 (2019)

http://dx.doi.org/10.3998/ticker.16481003.0003.202

(c) 2019 Christina Sylka, Zaida Diaz and Leigh Plummer

\section{External Factors Affect Both Libraries and Swamps}

ABLD members' year end reports also surfaced additional factors that have an impact on their libraries. Fifteen institutions discussed changing or increasing patron demands; twelve libraries expressed the impact of reduced or flat administrative budgets. Ten institutions spoke to the uncertainty bred by new or upcoming administrative changes at their libraries, business schools and universities. Search processes at these senior levels are even more complicated, challenging and slow than they are at the librarian and staff levels. At least five member institutions spoke to the ways in which librarians contributed to the profession. Three institutions were either needing or in the process of establishing a new strategic plan. Two member libraries highlighted the importance of communicating and proving the value and role of the library in the academic environment.

In terms of changing patron demands, New York University found that, after years of being focused on developing spaces for students, they have recently been experiencing increasing demand from faculty for dedicated spaces to work in the library when conducting research (ABLD, 2018, p. 31). While the University of Chicago library was focused on supporting graduate students for many years, they are now facing an expanding undergraduate college that has grown by approximately $20 \%$; while there are oncampus dormitories, the library is the only common gathering space, resulting in an increased use of the library as social space and a higher demand on staff time and resources in support of undergraduate users, a new user group (ABLD, 2018, pp. 54-55).

The University of Washington elevated the budget discussion to include the state level, recognizing that decisions and divisions in the state legislature and competition for state funds yield diminishing resources and unpredictable budgeting for business libraries, for the larger library systems in which they operate, and for universities themselves (ABLD, 2018, p. 27).

Contributions to the profession made by librarians at ABLD member institutions were a significant feature of reports. These contributions included conference presentations and posters, service to professional associations, and articles in books and journals, as well as through symposiums, workshops and other professional events.

\section{Conclusion}

Libraries, like swamps, are complex ecosystems that exist within and contribute to bigger systems. Sharing our experiences enables us to identify trends and similarities, as well as to acknowledge the complexity and variety that each institution faces.

\section{Bibliography}

Academic Business Library Directors (ABLD). (2018). Year in Review Report 2017/2018. Unpublished report.

BioDivCanada.ca. (2010). Wettands Retrieved from http://www.biodivcanada.ca/default.asp?lang=En\&n=F07D520A-1

Masters, P. (n.d.). Storm Surge Reduction by Wetlands. Retrieved from

https://www.wunderground.com/hurricane/surge wetlands.asp 
Ticker: The Academic Business Librarianship Review, 3:2 (2019)

http://dx.doi.org/10.3998/ticker.16481003.0003.202

(c) 2019 Christina Sylka, Zaida Diaz and Leigh Plummer

Nevala, K. (2018). In Defense of the Data Swamp. Dataversity. Retrieved from http://www.dataversity.net/defensedata-swamp

New Hampshire PBS. (2018). Wetlands. NatureWorks. Retrieved from http://www.nhptv.org/natureworks/nwep7e.htm

Schall, E. (1995). Learning to Love the Swamp. Journal of Policy Analysis and Management 14(2) pp 202-220 Retrieved from http://www.appam.org/assets/1/7/Schall Learning to Love the Swamp Reshaping Education for Public Servi ce.pdf

Shaw, E. (2018). Climate of Wetland Swamp Ecosystems. Retrieved from https://sciencing.com/climate-wetlandswamp-ecosystems-4535.html

Tkaczyk F. (n.d.). The Swamp Ecosystem: Ecology and Survival. Retrieved from https://www.wildernesscollege.com/swamp-ecosystem.html

University of British Columbia. (2018). Indian Residential School History and Dialogue Centre. Retrieved from https://ceremonies.ubc.ca/irshdc-opening/

U.S. Fish and Wildlife Service. (2018). National Wetlands Inventory. Retrieved from https://www.fws.gov/wetlands/

U.S. Environmental Protection Agency. (2016). Wetland Functions and Values. Retrieved from https://www.epa.gov/sites/production/files/2016-02/documents/wetlandfunctionsvalues.pdf 